\title{
NOTES ON GIANT OTTER (PTERONURA BRASILIENSIS) BEHAVIOR IN THE LAKE OF THE BALBINA HYDROELECTRIC POWER STATION, AMAZONAS, BRAZIL
}

\author{
Fernando C. Weber Rosas ${ }^{1,2}$ and Gália Ely de Mattos ${ }^{1}$
}

Since September 2001 the authors have been studying the reproductive period, vocalization, feeding habits and usage of the $3246 \mathrm{~km}^{2}$ lake of the Balbina hydroelectric power station by Pteronura brasiliensis (de Mattos et al., 20023; Zuanon et al., 20024; Rosas and de Mattos, 2003). In this note we describe some aspects of the behavior of giant otters in Balbina lake and compare them with the literature. We also report some new information on their reproductive behavior, which to our knowledge has not been published elsewhere.

On 21 August 2003 we observed that the den labeled JAU-7, located on one of the 3299 islands $\left(01^{\circ} 35^{\prime} 11.9^{\prime \prime} S\right.$, $\left.59^{\circ} 40^{\prime} 17.4^{\prime \prime} \mathrm{W}\right)$ of Balbina lake, was 'in use'. We decided to return there early the next morning in order to record the number of animals and their group composition. We arrived at JAU-7 at 05:51am on 22 August and remained in our aluminum boat, about $40 \mathrm{~m}$ from the den. A strong smell of feces and urine, characteristic of the communal latrines of $P$. brasiliensis, was noticed. At 06:18am a giant otter appeared in the den's entrance and left it, followed by another animal, and both started their morning routine of marking the land in front of the den. They were identified as an adult male (Male A) and a nursing female (Female N1) (Figure 1). The marking behavior was carried out by both animals, with the male spending a considerably longer time than the female in that process (the male spent $100 \%$ of the time marking the land, whereas the female spent $70 \%$ ). The female had very enlarged nipples, suggesting that she was nursing and probably with newborn cubs inside the den. Marking continued for $4 \mathrm{~min} 55 \mathrm{~s}$, during which time the animals entered the water and returned to the land in the area in front of the den, spreading urine with their paws. About 3 min after the couple had emerged from the den, two other individuals appeared, approaching from the water. These two animals noticed our presence

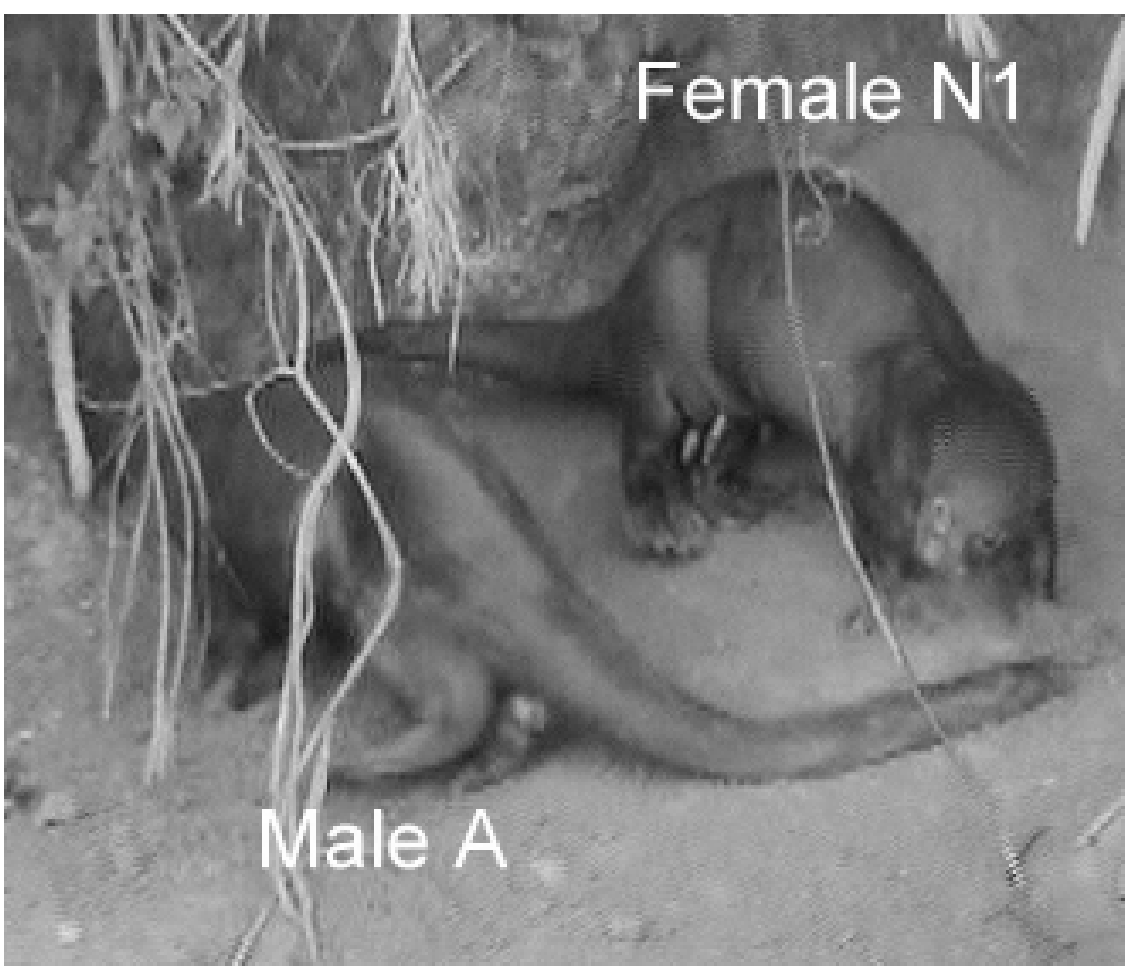

Figure 1. Adult male (Male A) and nursing female (Female N1) marking in front of the JAU-7 den. Balbina Lake, AM/Brazil. Photo: F. Rosas.

\footnotetext{
${ }^{1}$ Instituto Nacional de Pesquisas da Amazônia (INPA), Laboratório de Mamíferos Aquáticos. Caixa Postal 478, Manaus, AM, 69011-970, Brazil.

${ }^{2}$ E-mail: frosas@inpa.gov.br.

${ }^{3}$ De Mattos, G.E., Rosas, F.C.W., Picanço, M.C.L. and Lazzarini, S.M. (2002) Utilização do lago da Hidrelétrica de Balbina (Amazonas, Brasil) por Pteronura brasiliensis. Pages 74-75 in Abstracts, X Reunión de Trabajo de Especialistas en Mamíferos Acuáticos de América del Sur, 14-19 October, Valdivia, Chile.. ${ }^{4}$ Zuanon, J.A., de Mattos, G.E. and Rosas, F.C.W. (2002) Hábitos alimentares de Pteronura brasiliensis no lago da Hidrelétrica de Balbina, Amazônia Central, Brasil. Page 119 in Abstracts, X Reunión de Trabajo de Especialistas en Mamíferos Acuáticos de América del Sur, 14-19 October, Valdivia, Chile.
} 


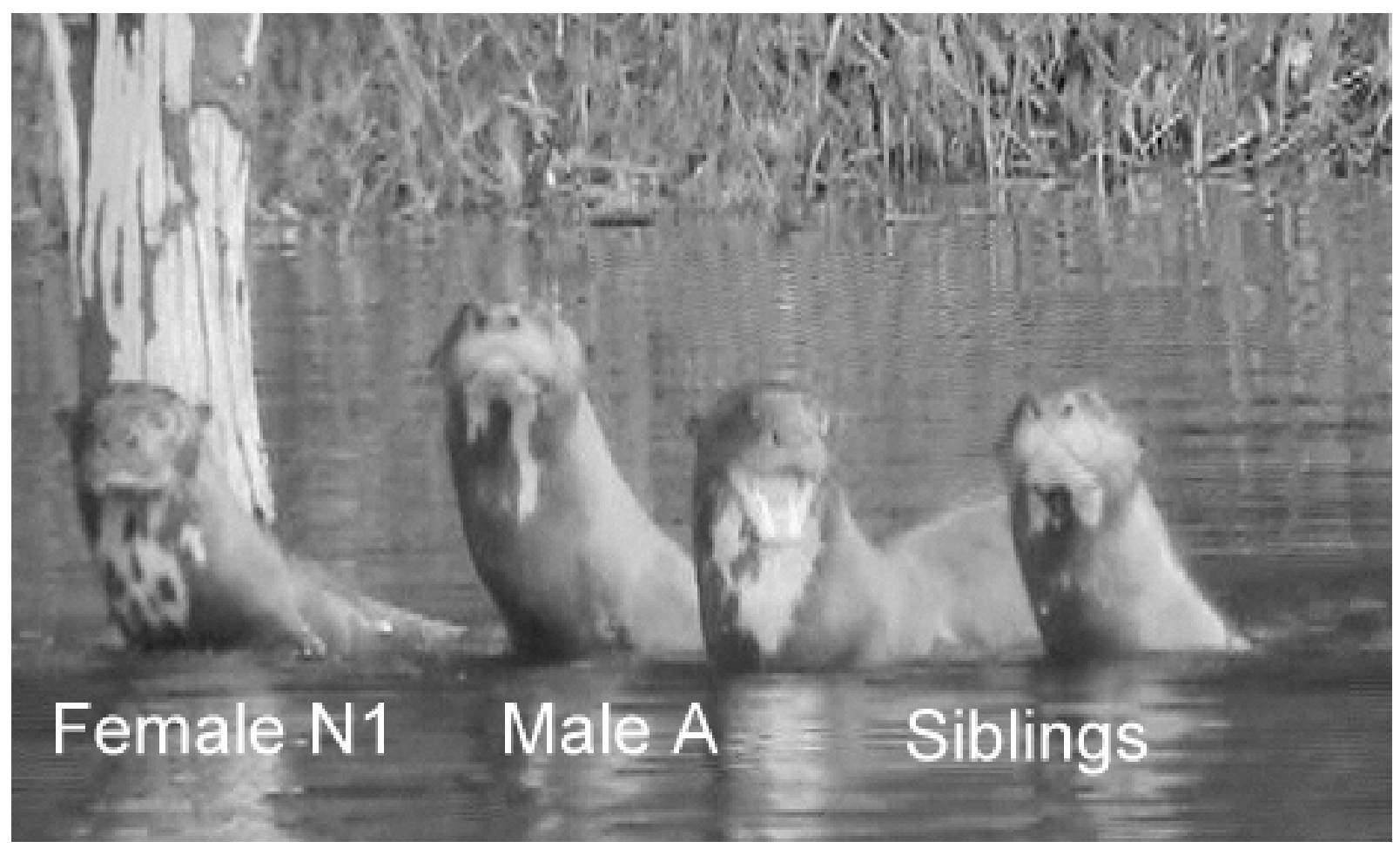

Figure 2. The four giant otters, from left to right: nursing female (Female N1), adult male (Male A) and the two siblings near the JAU7 den. Balbina Lake, AM/Brazil. Photo: F. Rosas.

and vocalized, alerting the couple (who was still in front of the den), which until that moment had not noticed us. The JAU-7 couple did not show any adverse reaction to the vocalization of the two approaching otters, indicating that the two individuals that appeared were members of the same group. The couple became alert due to the alarmed vocalization emitted by the individuals in the water and eventually noticed our presence, entered the water and joined the other two animals. The four otters remained a few more minutes in the area (Figure 2) and then swam away.

After they left the area, we approached the den and could hear the sounds of cubs inside it, confirming the presence of newborn animals. According to Duplaix (1980), it is normal that only the parents remain with cubs for the first six weeks to two months, after which time the sub-adults rejoin the family group again. This would explain why the other two giant otters that approached from the water did not sleep in the same den, despite belonging to the same family group. However, our attention was drawn to the fact that apparently the couple did not leave a 'baby sitter' in the den with such young cubs inside it.

In order to find out where the two approaching animals had slept, we cruised the nearby margins in the direction from where the two otters had arrived and found the den, which was located about 50m from JAU-7, where they had spent the night. We had already recorded family groups sub-dividing while foraging or escaping during the day on several occasions at Balbina lake. However, it was the first time we recorded the subdivision of family groups during the night at Balbina lake, confirming observations made by Duplaix (1980) in undisturbed areas. We then decided to leave the area and visit other dens previously marked by GPS in the lake. However, when we started the outboard engine, we observed that one more otter had left the JAU-7 den. It was another adult female (Female N2), also with very prominent nipples (Figure 3). This animal stayed about 30 s on land, in front of the den, and then entered the water. However, unlike the other four otters, she did not swim away from the area. In order to avoid causing further interference, we decided to leave the area and the female stayed in the den's vicinity.

It is not customary in $P$. brasiliensis that a single male be accompanied by two females which are nursing at the same time. According to Duplaix (1980), a female giant otter can have two litters in the interval of a few months if the first litter has been lost. However, the same author stresses the fact that the species forms stable couples, called alpha couples, which live together with the cubs until the latter eventually leave the family group prior to or at sexual maturity to form their own groups. Therefore, the second female could be the 'baby sitter', frequently recorded in P. brasiliensis (Carter and Rosas, 1997), although Schenck and Staib (1992) suggest that their presence is not obligatory. However, the very obvious nipples observed in this animal brings into 


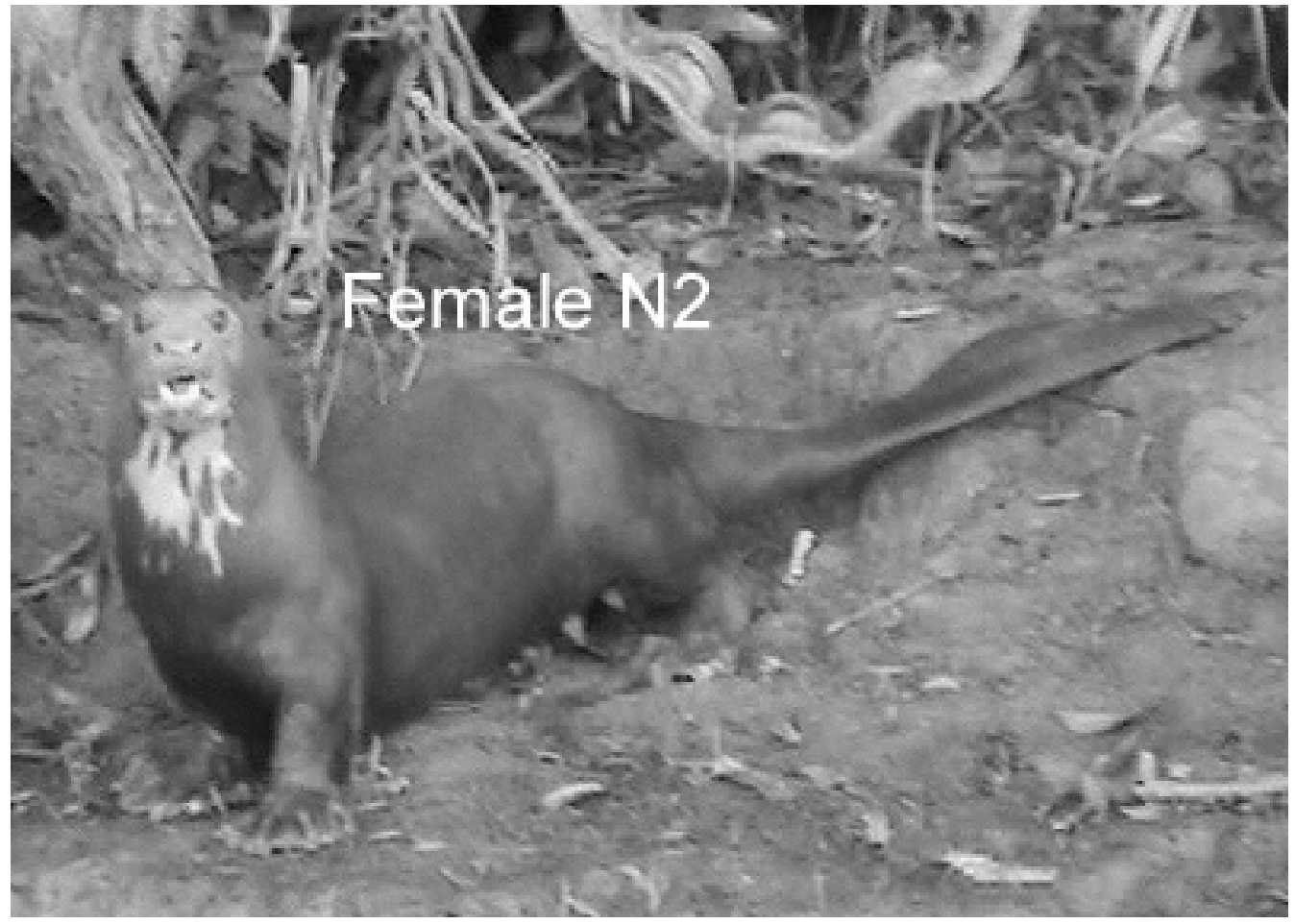

Figure 3. Nursing female (Female N2) in front of the JAU-7 den. Balbina Lake, AM/Brazil. Photo: F. Rosas.

question whether she was the 'baby sitter' or the cubs' mother. Even if one or both individuals that approached from the water, and whose sex we were unable to verify, was a male, it is unusual to have two females nursing at the same time in the same group unit. Another possibility would be 'psychological pregnancy' in one of the females, leading to prominent nipples. This has already been observed in a captive giant otter (F.C.W. Rosas, pers. obs.), and included the presence of milk in the mammary glands. However, we do not know if this can happen in free-ranging giant otters, making further investigations necessary in order to clarify the reproductive behavior observed.

\section{Acknowledgements}

We thank Centro de Preservação e Pesquisa de Mamíferos Aquáticos (CPPMA)/ Manaus Energia S.A. and ReBio Uatumã/IBAMA who provided logistical support in the field. We also thank Kesä K. Lehti and two anonymous referees for valuable comments and English review made on earlier drafts of this manuscript. We are grateful to Fundação O Boticário de Proteção à Natureza (project $n^{\circ} 053220021$ ) for the financial support given to our study.

\section{References}

Carter, S.K. and Rosas, F.C.W. (1997) Biology and conservation of the giant otter, Pteronura brasiliensis. Mammal Review 27(1): 1-26.

Duplaix, N. (1980) Observations on the ecology and behavior of the giant river otter Pteronura brasiliensis in Suriname. Rev. Ecol. (Terre Vie) 34: 195-620.

Rosas, F.C.W. and de Mattos, G.E. (2003) Natural deaths of giant otters (Pteronura brasiliensis) in Balbina hydroelectric lake, Amazonas, Brazil. IUCN Otter Specialist Group Bulletin, 20(2): 96-98.

Schenck, C. and Staib, E. (1992) Status, behaviour and protection of giant otter in Peru. Frankfurt Zoological Society Technical Report. 25pp. (unpublished). 
